\title{
Otoczenie archiwów w Polsce - PROJEKT BADAWCZY
}

http://dx.doi.org/10.12775/AKZ.2014.004

Słowa kluczowe: public relations w archiwach; otoczenie archiwów; archiwistyka projekt badawczy; zarządzanie archiwami; archiwoznawstwo

Ke y w ord s: public relations in archives; environment of archives; archival science - research project; archives management; knowledge of archives

\section{Streszczenie}

Artykuł jest omówieniem projektu badawczego, który zakłada przeprowadzenie badania otoczenia archiwów w Polsce i istniejących relacji pomiędzy archiwami a tym otoczeniem. Autorka stawia hipotezę badawczą, która zakłada, że wszystkie instytucje posiadają swoje wewnętrzne i zewnętrzne otoczenie, prezentuje stan wiedzy, przybliża koncepcję i plan badań, ich metodykę i założone efekty. Przeprowadzone badania pozwolą zdobyć wiedzę na temat archiwów jako instytucji, ich organizacji, zasad funkcjonowania, miejsca w społeczeństwie, a przede wszystkim na temat grup interesariuszy, z którymi archiwa stykają się w toku swej działalności, z dokładnym rozpoznaniem jakości zachodzących pomiędzy nimi relacji. 


\section{WPROWADZENIE}

„Public relations jest to planowa, ciągła i prowadzona z uwzględnieniem wyników systematycznych badań działalność, polegająca na przekazywaniu przez przedsiębiorstwo specjalnie przygotowanych w różnej formie informacji, w celu stworzenia w podmiotowym otoczeniu tego przedsiębiorstwa jego pożądanego obrazu, pozwalającego na lepsze zintegrowanie się z tym otoczeniem oraz ułatwiającego realizację podstawowych celów przedsiębiorstwa. Działalność ta może być prowadzona także przez inne organizacje, w tym nie nastawione na osiąganie zysku" ". To jedna z najpełniejszych definicji public relations. Jej autor zwraca uwagę na przynajmniej trzy zasadnicze kwestie. Po pierwsze, mówi o tym, że działania z zakresu public relations muszą być prowadzone w sposób planowy i ciągły, a być przygotowane i realizowane w oparciu o wyniki systematycznych badań, prowadzonych na różnych etapach prac. Po drugie, podmiotem prowadzonych działań jest otoczenie instytucji, które jest jednocześnie adresatem strategii działania i jej recenzentem, to od niego bowiem zależy sukces lub porażka przyjętej filozofii postępowania i stopień realizacji założeń. I po trzecie, autor jednoznacznie stwierdza, że działania z zakresu public relations mogą być realizowane przez podmioty niekomercyjne, nie nastawione na zysk.

Odnosząc się do przywołanej definicji i z uwagi na temat rozważań, chciałabym zwrócić uwagę na trzy kwestie: potrzebę prowadzenia badań, otoczenie instytucji oraz public relations podmiotów niekomercyjnych.

Badania w PR prowadzone są w celu poznania sytuacji wyjściowej instytucji, analizy i charakterystyki grup docelowych, weryfikacji założeń i realizacji strategii, w tym także doboru narzędzi, oraz w celu poznania efektów prowadzonych działań wraz z możliwością przeprowadzenia oceny i wyciągnięcia wniosków. Anna Miotk pyta: po co stosować badania w PR ?² I odpowiada, że - i trudno się z nią nie zgodzić - badania pozwalają lepiej poznać postawy grup docelowych, trafić do nich z przekazem i zachęcić do oczekiwanego działania, wykorzystać adekwatne do założonych celów i najbardziej skuteczne narzędzia, a także zaoszczędzić czas i energię, która nierzadko jest marnowana na działania nieprzynoszące pożądanych efektów. Ponad to, ba-

1 W. Budzyński, Public Relations. Zarzadzanie reputacja firmy, Warszawa 2000, s. 11.

2 A. Miotk, Badania w Public Relations. Wprowadzenie, Warszawa 2012, s. 19. 
dania pozwalają zgromadzić dużą liczbę informacji, które są niezbędne do opracowania strategii PR, bez nich będzie ona bowiem mało dokładna, realizowana „po omacku”, a jej ocena końcowa wręcz niemożliwa.

Podmiotem prowadzonych w ramach PR działań i jednocześnie jednym z obszarów prowadzonych badań jest otoczenie instytucji. Otoczeniem instytucji nazywamy tą część społeczeństwa, która ma z organizacją co najmniej jeden wspólny interes ${ }^{3}$. Nie musi być to jednak interes zgodny. Pod pojęciem „interes” należy bowiem rozumieć zarówno interesy natury materialnej, jak i fundamentalne wartości, wymagania i oczekiwania grup, zbiorowości i składających się na nie jednostek. Interesy organizacji i jej otoczenia mogą być tożsame, mogą się wzajemnie dopełniać, krzyżować lub łączyć albo też być sprzeczne.

Działania z zakresu public relations mogą być realizowane zarówno przez podmioty komercyjne, jak i niekomercyjne, nienastawione na zysk. Będą to zatem instytucje z takich obszarów jak: edukacja, kultura i nauka, administracja publiczna, ochrona zdrowia i obrona kraju czy działalność charytatywna. W tej grupie znajdą się także archiwa, jako instytucje w większości przypadków niekomercyjne i nienastawione na materialne korzyści.

Celem niniejszego artykułu jest zwrócenie uwagi środowiska na kwestię otoczenia archiwów w Polsce, jako podmiotu działań public relations, i potrzeby jego poznania. Wychodząc od definicji PR, chciałam po raz kolejny wyraźnie powiedzieć, że archiwa mają pełne prawo, na równi z podmiotami komercyjnymi, korzystać z narzędzi i zasad prowadzenia public relations, że zapożyczenia ze świata marketingu są nie tylko nieuniknione, ale i bardzo pomocne, że PR to nie są pojedyncze wydarzenia, a realizacja zaplanowanej strategii, co więcej, są to działania poparte badaniami. W tym tekście chciałabym skupić się na badaniach otoczenia archiwów, czyli tej części społeczeństwa, którą archiwa się interesują i która się nimi interesuje obecnie lub może być zainteresowana w przyszłości.

Prowadzone badania nad otoczeniem archiwów powinny umożliwić jego identyfikację i analizę, czyli dać możliwość zdefiniowania grup osób fizycznych i prawnych, z którymi archiwa stykają się w toku prowadzonej przez siebie działalności, w wymiarze wewnętrznym i zewnętrznym. Badanie powinno pokazać same relacje, ich jakość, długość trwania, znaczenie i konsekwencje, które ze sobą niosą wraz z identyfikacją wykorzystywanych narzędzi i mecha-

${ }^{3}$ K. Wojcik, Public relations. Wiarygodny dialog z otoczeniem, Warszawa 2005, s. 52 
nizmów. Pośrednim celem takiego badania powinna być analiza struktury organizacyjnej archiwów i ocena jej wpływu na nawiązywane relacje.

\section{Hipoteza BADAwCZA}

Hipoteza badawcza zakłada, iż każda instytucja bez względu na profil swojej działalności funkcjonuje w określonym środowisku. Wokół niej tworzy się charakterystyczne dla niej otoczenie, z którym utrzymuje określone relacje. Archiwa także mają swoje, specyficzne otoczenie, i to zarówno w wymiarze wewnętrznym, jak i zewnętrznym. Identyfikacja jego jest niezbędna do przygotowania strategii komunikacyjnej, dobrania odpowiednich narzędzi i środków komunikowania dostosowanych do potrzeb i oczekiwań określonych grup interesariuszy. Pozwala w pełni poznać instytucję, osadzić w określonym kontekście, zdefiniować sieć kontaktów i powiązań. A także stanowi punkt wyjścia wszelkich działań komunikacyjnych oraz marketingowych, również tych z obszaru promocji. Daje możliwość budowania korzystnych relacji ze zidentyfikowanym otoczeniem, zaznaczenia obecności instytucji w społeczeństwie i jasnego określenia pełnionej w nim funkcji. Korzyści płynące z nawiązania i utrzymywania dobrych relacji można analizować sensu largo - z punktu widzenia całej branży, dyscypliny naukowej, zmiany świadomości społecznej, sposobu postrzegania archiwów oraz sensu stricto - z punktu widzenia pojedynczego archiwum, które funkcjonuje na danym obszarze i jest postrzegane jako cząstka określonej społeczności.

Pojęcie „archiwum” jest wieloznaczne i jeśli nawet rozpatrujemy je w ujęciu instytucjonalnym, to instytucje te różnią się między sobą. Należy jednak założyć, że pewna część ustaleń będzie miała charakter jednostkowy, indywidualny przyjęty dla danej instytucji lub grupy instytucji, inna natomiast pozwoli wyciągnąć wnioski generalne.

\section{STAN WIEDZY}

Tak postawiony problem badawczy ma charakter w pełni nowatorski. Po raz pierwszy bowiem proponuje się spojrzenie na archiwa przez pryzmat ich otoczenia i nawiązywanych z nim relacji. Takie spojrzenie daje możliwość rozpoznania grup odbiorców działań, które archiwa podejmują w toku swojej działalności, czyli podczas realizacji swych podstawowych funkcji. Pogłębiona 
analiza pozwoli na zdobycie wiedzy teoretycznej, nazwanie zachodzących zjawisk, wskazanie nowych obszarów, a wszystko to po to, by zmienić postawę z pasywnej na aktywną, by odpowiednio dobrać narzędzia komunikowania, a także uświadomić i samym archiwistom, i odbiorcom usług archiwalnych, jak szeroki jest profil ich działalności, jak wiele mają okazji do zdobywania dobrego publicity, a także jak stosunkowo łatwo kształtować dobry wizerunek archiwów.

Korzyści płynące z marketingowego spojrzenia na instytucję niedochodową zauważyły już dawno biblioteki ${ }^{4}$. Publikowane opracowania dotyczą przede wszystkim kwestii wizerunkowych, nowych technologii oraz obsługi czytelników. Dziś widać tego efekty. Biblioteki zmieniają się w sposób dynamiczny, dostosowując swój profil działalności do potrzeb współczesnego otoczenia. Stereotypowe myślenie o książnicach coraz częściej odstaje od rzeczywistości. To dobry kierunek zmian, kierunek, który polskie archiwa powinny objąć.

Międzynarodowe gremia archiwalne także coraz częściej zwracają uwagę na problem promocji archiwów, popularyzację wiedzy na ich temat, wykorzystania narzędzi i mechanizmów marketingowych w działalności archiwów. Podobnie jest $\mathrm{z}$ archiwami europejskimi ${ }^{5}$.

Polski dorobek na tym polu jest jednak ciągle dość skromny. Sprowadza się przede wszystkim do tomu pokonferencyjnego wydanego przez Stowarzyszenie Archiwistów Polskich oraz kilkunastu artykułów piszącej te słowa $^{6}$. W tomie zostały zebrane teksty autorów polskich i obcych wygłoszone

${ }^{4}$ M.in.: J. Wojciechowski, Marketing $w$ bibliotece, Warszawa 1993; E. Mostowicz, Marketing $w$ dziatalności bibliotek i ośrodków informacji, „Przegląd Biblioteczny” 1992 nr 1/4, s. 35-44; Zastosowania marketingu w bibliotekach, red. R. Cybulski, Warszawa 1997; E. Zybert, Kultura organizacyjna w bibliotekach, Warszawa 2004; B. Żołędowska-Król: Wizerunek biblioteki publicznej, Katowice 2006; W. Tyszka, Public relations w Bibliotece Narodowej, „Bibliotekarz” 2000, nr 12, s. 16-18.

${ }^{5}$ M.in.: R. Arovelius, Public relations $w$ archiwach szwedzkich, [w:] Public relations $w$ archiwach. Zbiór studiów, red. M. Jabłońska, Poznań 2010, s. 109-117; I. Buzaite, Public relations in Lithuanian archives: today's situation and perspective, [w:] tamże, s. 119-125; D. Joita, Doing PR for archives Romania, [w:] tamże, s. 127-144; Z. Kollarova, Public relations archiwów państwowych $w$ Stowacji, [w:] tamże, s. 145-150; H. Krajewska, Public relations w Austriii Niemczech, [w:] tamże, s. 151-160; W. Stępniak, Promocja I popularyzacja dziatalności archiwów w pracach Międzynarodowej Rady Archiwów, [w:] tamże, s. 37-54.

${ }^{6}$ Wspominany zbiór studiów pt. Public relations $w$ archiwach oraz m.in.: M. Jabłońska, H. Robótka, Budowanie wizerunku archiwum, [w:] Archiwa w nowoczesnym spote- 
podczas konferencji „Public relations w archiwach”, która została zorganizowana w ramach cyklu „Wiosenne spotkania archiwalne” w 2008 r. Traktują one o różnych problemach związanych z public relations w archiwach, w tym także o ich otoczeniu. W większości przypadków są to jednak prace, które powstały w oparciu o obserwację i wiedzę ogólną, a nie pogłębione badania. Wyniki przeprowadzonych analiz często są dość powierzchowne, a wnioski wysnute na zasadzie odwzorowania. Pewnym dopełnieniem tego dorobku mogą być artykuły poświęcone różnym formom pracy archiwów w obrębie działań popularyzatorskich, działań edukacyjnych, działań wizerunkowych czy też traktujące o jednostkowych podmiotach otoczenia np. użytkowni$k^{k}{ }^{7}$. Pewnym krokiem na przód są także pojedyncze prace powstające na seminarium dyplomowym prof. Haliny Robótki, które w całości są poświęcone właśnie problematyce otoczenia archiwów ${ }^{8}$.

czeństwie. Pamiętnik V Powszechnego Zjazdu Archiwistów Polskich, Olsztyn 6-8 września 2007 r., red. J. Porazinski i K. Stryjkowski, Warszawa 2008, s. 363-366; M. Jabłońska, Communico ergo sum. Czy potrzebna nam poprawna komunikacja w archiwum?, „Archiwista Polski” 2007, nr 2, s. 93-104, taż, Komunikacja spoteczna i public relations w archiwach. Zarys problematyki badawcze, [w:] Archiwa - Kancelarie - Zbiory, red. W. Chorążyczewski, R. Degen, K. Syta, t. 2, Toruń 2008, s. 63-80; taż, Komunikacja spoteczna na studiach archiwistycznych jako krok ku poprawie wizerunku archiwów polskich, [w:] Toruńskie konfrontacje archiwalne, red. W. Chorążyczewski i A. Rosa, t. 1: Archiwistyka na uniwersytetach. Archiwistyka w archiwach, Toruń 2009, s. 241-250; taż, Panel dyskusyjny „Wizerunek archiwów polskich. Wiele narzędzi jeden cel”, „Archiwista Polski” 2009, nr 4, s. 69-77 (współautor); taż, Konkurs na najlepsza pracę dyplomowa z zakresu archiwistyki jako narzędzie zdobywania dobrego publicity, „Archiwista Polski” 2011, nr 1, 2011, s. 75-83; taż, Public relations $w$ archiwach - wprowadzenie, [w:] Public relations $w$ archiwach, s. 25-36.

7 M.in.: Archiwa i ich użytkownicy, red: A. Krzemińska, Katowice 2007; A. Rosa, Wystawy archiwalne w stużbie polityki historycznej państwa. Funkcja propagandowa wystaw archiwalnych $w$ Polsce Ludowej, „Archiwista Polski” 2008, nr 4, s. 43-69; taż, Funkcja edukacyjna archiwów, Warszawa, 2012; K. Syta, Archiwista i archiwum w oczach użytkownika, [w:] Toruniskie konfrontacje archiwalne, s. 251-263.

${ }^{8}$ M. Kaźmierska, „Otoczenie Archiwum Państwowego w Poznaniu Oddział w Gnieźnie”, praca licencjacka, 2009/2010, promotor prof. H. Robótka, dostęp w Archiwum Prac Dyplomowych UMK [dalej: APD UMK]; B. Pochylska, „Otoczenie Fundacji Generał Elżbiety Zawackiej. Archiwum i Muzeum Pomorskie Armii Krajowej oraz Wojskowej Służby Polek”, praca licencjacka, 2009/2010, promotor prof. H. Robótka, dostęp w APD UMK; A. Jarzębowska, „Otoczenie archiwum zakładowego na przykładzie firmy ENERGA OPERATOR S.A. Oddział w Toruniu”, praca licencjacka, promotor prof. H. Robótka, dostęp w APD UMK. 
Wyraźnie należy jednak powiedzieć, że dorobek naukowy z zakresu samego otoczenia archiwów jest rzeczywiście minimalny. Zagadnienie to jest podejmowane jedynie w kontekście public relations, wizerunku, promocji i popularyzacji, ale traktowane zawsze w sposób marginalny, jako dodatek do rozważań, a nie ich przedmiot. Jest to także dowód na to, iż podjęty problem badawczy jest tematem całkowicie nowym, który wymaga zdecydowanie bardziej zaawansowanych prac.

Niezastąpiona w pracach badawczych nad podjętym tematem jest natomiast literatura ogólna, branżowa z zakresu marketingu, public relations i komunikacji. Stanowi ona podstawę prowadzonych badań. Daje punkt odniesienia. Tutaj literatura jest bogata i dzięki temu można zestawiać ją w różnych konfiguracjach, od zagadnień ogólnych po bardzo szczegółowe? .

\section{KONCEPCJA I PLAN BADAŃ}

Projekt badawczy ma na celu zbadanie otoczenia archiwów w Polsce, jego identyfikację i charakterystykę oraz analizę zachodzących pomiędzy archiwami a ich otoczeniem relacji. Archiwa nie są jednak instytucjami jednorodnymi, co zostało już powiedziane. Różni je wiele: profil i zasięg prowadzonej działalności, stopień autonomii, przynależność do sieci lub jej brak, rodzaj podległość, dalej struktura organizacyjna, drogi akcesji gromadzonych materiałów, specyfika zasobu, personel czy priorytety działania.

Ażeby zapanować nad tą różnorodnością, konieczna jest pewna generalizacja. Można tu wykorzystać zaproponowany w 2008 r. przez piszącą te słowa podział archiwów na cztery grupy: archiwa jako instytucje samodzielne, archiwa jako komórki organizacyjne, archiwa społeczne i ośrodki dokumentacyjne oraz archiwa jako instytucje komercyjne ${ }^{10}$. Kluczem podziału były tu różne drogi akcesji gromadzonych materiałów oraz forma organizacji insty-

9 M.in.: M. A. Mach, Temporalna analiza otoczenia przedsiębiorstwa: techniki i narzędzia inteligentne, Wrocław 2007; Metody organizacji i zarządzania: ksztattowanie relacji organizacyjnych, red. W. Błaszczyk, Warszawa 2005; S. Kaczmarczyk, Zastosowania badań marketingowych: zarządzanie marketingowe i otoczenie przedsiębiorstwa, Warszawa 2007 oraz W. Budzyński, dz. cyt.; K. Wojcik, dz. cyt.; A. Żbikowska, Public relations, Warszawa 2005; D. Tworzydło, Public relations. Teoria i studia przypadków, Rzeszów 2003; Public relations. Doskonalenie procesu komunikowania, red. A. Adamus-Matuszyńska i R. Maćkowska, Katowice 2012.

10 Public relations $w$ archiwach, s. 28-29. 
tucji. Jak każda generalizacja, pewnie i ta obciążona jest ryzykiem błędu, ale na tym etapie prac pozwala ująć w określone ramy archiwa różnych typów i różnych szczebli. Zaproponowany podział nie zawsze pokrywa się z przyjętą $\mathrm{w}$ archiwistyce systematyzacją archiwów, ale przy rozważaniach nad otoczeniem archiwów wydaje się optymalny.

Pierwszą grupę stanowią archiwa będące instytucjami samodzielnymi, choć nierzadko funkcjonującymi w sieci. Archiwa, na czele których stoi dyrektor, posiadające rozbudowaną strukturę organizacyjną oraz określoną autonomię. Archiwa te przechowują zarówno państwową, jak i niepaństwową część narodowego zasobu archiwalnego, a ich cechą wyróżniającą jest zagwarantowany określonymi przepisami prawa stały dopływ materiałów w przeszłości lub współcześnie. Są to m.in. archiwa państwowe centralne i terenowe, archiwa kościelne archidiecezjalne i diecezjalne, archiwa wojskowe. W tej grupie znajdą się także archiwa Instytutu Pamięci Narodowej, które co prawda zalicza się do archiwów z powierzonym zasobem, ale które cechuje zarówno rozbudowana struktura, określona samodzielność, jak i zagwarantowane źródło akcesji materiałów archiwalnych.

Drugą grupę stanowią archiwa będące komórkami organizacyjnymi określonych instytucji: archiwa zakładowe (zgodnie z zapisem ustawy archiwalnej są to komórki organizacyjne w państwowych i samorządowych jednostkach organizacyjnych wytwarzających materiały archiwalne), składnice akt (zgodnie z zapisem ustawy archiwalnej są to komórki organizacyjne w państwowych i samorządowych jednostkach organizacyjnych wytwarzających dokumentację niearchiwalną), archiwa z powierzonym zasobem, w szczególności archiwa uczelniane, Archiwum Polskiej Akademii Nauk czy Archiwum Nauki PAN i PAU, archiwa wyodrębnione, m.in. Archiwum Sejmu, Archiwum Prezesa Rady Ministrów, Archiwum Ministerstwa Spraw Zagranicznych czy Główne Archiwum Policji, a także archiwa przejściowe, które nierzadko mają także charakter archiwów komercyjnych.

Trzecią grupę stanowią archiwa społeczne i ośrodki dokumentacyjne. Instytucje, które działają w charakterze fundacji, które zabiegać muszą o środki na swą działalność oraz we własnym zakresie pozyskiwać materiały archiwalne. W tym przypadku dbałość o dobre relacje z otoczeniem ma zasadniczy wpływ na charakter zasobu, na jego wielkość i jakość. Lista tych instytucji jest dość długa. Badaniu zostanie poddana niewielka ich część, wyselekcjonowana z uwagi na profil działalności oraz obszar działania. 
Ostatnią grupę stanowią instytucje o charakterze komercyjnym prowadzące zarobkową działalność przechowalniczą. Nierzadko bardzo dobrze zorganizowane, o dużym obszarze działania, profesjonalnie wyposażone, pracujące na własną markę. Są to archiwa, którym najbliżej do świata marketingu, głównie ze względu na czerpane ze swej działalności korzyści finansowe. $\mathrm{W}$ archiwach tych pozytywny rozgłos przekłada się na liczbę depozytariuszy, a zaufanie społeczne, na które pracują, sprawia, że stają się wiarygodnymi kontrahentami. To zupełnie inny typ archiwów niż te charakteryzowane w grupach wcześniejszych, ale to także archiwa, a ich wizerunek rzutuje na wizerunek całej branży.

Wszystkie archiwa łączy przede wszystkim to, iż każde z nich, choć zapewne z różnym natężeniem, realizuje cztery podstawowe funkcje: gromadzenie, przechowywanie, opracowanie i udostępnianie. Realizacja tych funkcji determinuje określony kanon zadań, a to wiąże się z wyznaczeniem określonego obszaru relacji, kontaktów pomiędzy archiwum a jego interesariuszami: grupami instytucji, pojedynczymi instytucjami czy osobami. Funkcje przekładają się bezpośrednio na zadania, które realizują pracownicy instytucji. Zatem obok relacji zewnętrznych konieczne będzie prześledzenie kontaktów wewnątrz instytucji i wskazanie osób odpowiedzialnych za kontakty z otoczeniem.

Plan badań zakłada w pierwszej kolejności stworzenie listy archiwów poddanych badaniu, opracowanie kryteriów selekcji i wyznaczenie tych jednostek, które kryteria te spełniają i które uznać można za reprezentatywne. Wstępne rozpoznanie wskazuje na potrzebę przeprowadzenia badania w przynajmniej 10 wytypowanych instytucjach w obrębie każdej z grup. Łącznie badaniu będzie poddanych 40 instytucji. Zebranie materiału wymaga wizyty w konkretnym archiwum i przeprowadzenie tam kwerendy. Kolejną czynnością będzie analiza zgromadzonego materiału. Najpierw w obrębie instytucji, z podziałem na realizowane funkcje, następnie w obrębie grup i dalej, analiza całościowa zakończona wyciągnięciem wniosków generalnych. Zwieńczeniem prac będzie redakcja wyników badań.

\section{MetOdYKA BADAŃ}

Badanie otoczenia archiwów polskich i relacji zachodzących pomiędzy nimi a grupami interesariuszy wymaga przeprowadzenia kwerendy w blisko 40 instytucjach, z podziałem na cztery grupy archiwów. Kwerenda polegała będzie 
na zapoznaniu się $\mathrm{z}$ działaniami podejmowanymi przez archiwum $\mathrm{w}$ toku realizacji czterech podstawowych funkcji: gromadzenie, przechowywanie, opracowanie i udostępnianie. Materiałem badawczym będą akta własne instytucji zgromadzone w registraturze bądź zdeponowane w archiwum bieżącym. Badanie będzie obejmowało działania podejmowane w przeciągu ostatnich 10 lat, z tą jednak świadomością, że otoczenie ma charakter zmienny, ewoluuje i dlatego też ważne, żeby podczas kwerendy uchwycić mechanizmy działań, a nie tylko samych zdarzeń. Dane z akt własnych powinny być uzupełnione o informacje zdobyte podczas rozmów z kierownictwem instytucji oraz z pracownikami. Wymagać to będzie studiów wstępnych nad instytucją, rozpoznania struktury organizacyjnej, statutu oraz zakresu obowiązków. Studia te pozwolą także na identyfikację otoczenia wewnętrznego i ocenę jego wpływu na podejmowane w toku działalności instytucji działania. W tym przypadku także ogólnodostępne normatywy i wyniki kwerendy w aktach własnych będzie trzeba poszerzyć o rozmowy z kierownictwem i pracownikami. Na potrzeby gromadzenia materiału oraz sprawniejszej jego analizy zostanie opracowany formularz badawczy. W ten sposób każda z instytucji zostanie zbadana według modelu wzorcowego, a zebrany materiał będzie miał stałą strukturę.

Kolejną czynnością będzie analiza zgromadzonego materiału. Najpierw zostanie ona przeprowadzona w obrębie badanej instytucji. Pozwoli to na identyfikację otoczenia, poszczególnych grup interesariuszy, wskazanie obszarów zagospodarowanych i do zagospodarowania. Pozwoli także na identyfikację i ocenę wykorzystywanych narzędzi i podejmowanych działań pod kątem ich skuteczności. Pokaże otoczenie wewnętrzne i wskaże osoby odpowiedzialne za poszczególne działania. Drugi etap analizy polegał będzie na spojrzeniu na każdą z grup archiwów jako na całość. Dziesięć archiwów stworzy obraz jednej grupy. Możliwe będzie wówczas przeprowadzenie oceny konkretnego profilu archiwów. Ostatni etap to analiza globalna, całościowa. Zebrany materiał, poddany obróbce, pozwoli wysunąć wnioski generalne i stworzyć charakterystykę otoczenia archiwów polskich wraz z omówieniem zachodzących relacji pomiędzy archiwami a ich grupami interesariuszy. Wnioski zostaną poddane redakcji, a następnie publikowane. 


\section{ZAŁOŻONE EFEKTY}

Projekt zakłada przeprowadzenie badania otoczenia archiwów w Polsce i istniejących relacji pomiędzy archiwami a tym otoczeniem. Efektem prac będzie zdobycie wiedzy na temat archiwów jako instytucji, ich organizacji, zasad funkcjonowania, miejsca w społeczeństwie, a przede wszystkim wiedzy na temat grup interesariuszy, z którymi archiwa stykają się w toku swej działalności, z dokładnym rozpoznaniem jakości zachodzących pomiędzy nimi relacji. Zdobyta wiedza będzie miała przełożenie na rozwój badań z zakresu archiwoznawstwa, ze szczególnym uwzględnieniem nauk zarządczych, a wnioski teoretyczne mogą uzyskać wymiar praktyczny, jeśli zainteresowane podmioty wykorzystają je w swej pracy zawodowej. Zebrany materiał może posłużyć także jako podstawa do prac nad strategią komunikacyjną instytucji, nad doborem narzędzi komunikacyjnych i pozyskiwaniem nowych grup interesariuszy i pielęgnowaniem istniejących relacji. Jednym słowem badania te mają stworzyć podwaliny pod proces zmiany myślenia o archiwach i wdrożenia w nich zasad zarządzania marketingowego. W dalszej perspektywie polepszenie relacji z otoczeniem przełożyć się może na poprawę świadomości archiwalnej społeczeństwa, zmianę stereotypowego wizerunku archiwów oraz podniesienie prestiżu zawodu.

Przedstawiony projekt ma zatem zarówno znaczenie teoretyczne, jak i praktyczne, pozwala bowiem wyznaczyć nowy obszar badawczy, co może wpłynąć na dalszy rozwój dyscypliny, a także daje archiwum narzędzie do działania, wskazuje punkt wyjścia do prowadzenia aktywnej i świadomej polityki komunikacyjnej.

Nowatorski charakter badań i wnioski z nich płynące dadzą zapewne bardzo ciekawy materiał do publikacji. Wymiernym i udokumentowanym efektem podjętego problemu będzie samodzielna publikacja lub obszerny artykuł w czasopiśmie branżowym. 


\section{Marlena JabŁońsKa}

Bibliografia:

Archiwa i ich użytkownicy, red. A. Krzemińska, Katowice, 2007.

Arovelius Renata, Public relations $w$ archiwach szwedzkich, [w:] Public relations $w$ archiwach. Zbiór studiów, red. M. Jabłońska, Poznań 2010.

Budzyński Wojciech, Public Relations. Zarządzanie reputacją firmy, Warszawa 2000.

Buzaite Irma, Public relations in Lithuanian archives: today's situation and perspective, [w:] Public relations w archiwach. Zbiór studiów, red. M. Jabłońska, Poznań 2010.

Jabłońska Aleksandra, Jabłońska Marlena, Panel dyskusyjny „Wizerunek archiwów polskich. Wiele narzędzi jeden cel”, „Archiwista Polski” 2009, nr 4.

Jabłońska Marlena, Communico ergo sum. Czy potrzebna nam poprawna komunikacja w archiwum?, „Archiwista Polski” 2007, nr 2.

Jabłońska Marlena, Komunikacja spoteczna i public relations w archiwach. Zarys problematyki badawczej, [w:] Archiwa - Kancelarie - Zbiory, red. W. Chorążyczewski, R. Degen, K. Syta, t. 2, Toruń 2008.

Jabłońska Marlena, Komunikacja spoteczna na studiach archiwistycznych jako krok ku poprawie wizerunku archiwów polskich, [w:] Torunskie konfrontacje archiwalne, red. W. Chorążyczewski i A. Rosa, t. 1: Archiwistyka na uniwersytetach. Archiwistyka w archiwach, Toruń 2009.

Jabłońska Marlena, Konkurs na najlepsza prace dyplomowa z zakresu archiwistyki jako narzędzie zdobywania dobrego publicity, „Archiwista Polski” 2011, nr 1.

Jabłońska Marlena, Public relations w archiwach - wprowadzenie, [w:] Public relations w archiwach. Zbiór studiów, red. M. Jabłońska, Poznań 2010.

Jabłońska Marlena, Robótka Halina, Budowanie wizerunku archiwum, [w:] Archiwa w nowoczesnym spoteczeństwie, Pamiętnik V Powszechnego Zjazdu Archiwistów Polskich, Olsztyn 6-8 września 2007 r., red. J. Porazinski i K. Stryjkowski, Warszawa 2008.

Joita Diana, Doing PR for archives Romania, [w:] Public relations w archiwach. Zbiór studiów, red. M. Jabłońska, Poznań 2010.

Kaczmarczyk Stanisław, Zastosowania badań marketingowych: zarzadzanie marketingowe i otoczenie przedsiębiorstwa, Warszawa 2007.

Kollarova Zuzana, Public relations archiwów państwowych w Stowacji, [w:] Public relations w archiwach. Zbiór studiów, red. M. Jabłońska, Poznań 2010.

Krajewska Hanna, Public relations $w$ Austrii i Niemczech, [w:] Public relations $w$ archiwach. Zbiór studiów, red. M. Jabłońska, Poznań 2010.

Mach Maria A., Temporalna analiza otoczenia przedsiębiorstwa. Techniki i narzędzia inteligentne, Wrocław 2007.

Metody organizacji i zarzadzania: ksztattowanie relacji organizacyjnych, red. W. Błaszczyk, Warszawa 2005.

Miotk Anna, Badania w Public Relations. Wprowadzenie, Warszawa 2012. 
Mostowicz Emilia, Marketing $w$ dziatalności bibliotek i ośrodków informacji, „Przegląd Biblioteczny" 1992, nr 1/4.

Public relations. Doskonalenie procesu komunikowania, red. A. Adamus-Matuszyńska i R. Maćkowska, Katowice 2012.

Rosa Agnieszka, Funkcja edukacyjna archiwów, Warszawa, 2012.

Rosa Agnieszka, Wystawy archiwalne w stużbie polityki historycznej państwa. Funkcja propagandowa wystaw archiwalnych w Polsce Ludowej, „Archiwista Polski” 2008, nr 4.

Stępniak Władysław, Promocja i popularyzacja dziatalności archiwów w pracach Międzynarodowej Rady Archiwów, [w:] Public relations w archiwach. Zbiór studiów, red. M. Jabłońska, Poznań 2010.

Syta Krzysztof, Archiwista i archiwum w oczach użytkownika, [w:] Toruńskie konfrontacje archiwalne, , red. W. Chorążyczewski i A. Rosa, t. 1: Archiwistyka na uniwersytetach. Archiwistyka warchiwach, Toruń 2009.

Tworzydło Dariusz, Public relations. Teoria i studia przypadków, Rzeszów 2003.

Tyszka Wojciech, Public relations w Bibliotece Narodowej, „Bibliotekarz” 2000, nr 12.

Wojciechowski Jacek, Marketing w bibliotece, Warszawa 1993.

Wojcik Krystyna, Public relations. Wiarygodny dialog z otoczeniem, Warszawa 2005.

Zastosowania marketingu w bibliotekach, red. R. Cybulski. Warszawa 1997.

Zybert Elżbieta, Kultura organizacyjna w bibliotekach, Warszawa 2004.

Żbikowska Agnieszka, Public relations, Warszawa 2005.

Żołędowska-Król Beata, Wizerunek biblioteki publicznej, Katowice 2006.

\section{Summary \\ Environment of archives in Poland - a research project}

The article discusses a research project that intends to study the environment of archives in Poland and existing relations between archives and the environment. The Author formulates a research hypothesis that all institutions have their inside and outside environment; she presents the present knowledge of the subject, and introduces the concept and research schedule, its methodology and supposed effects. This research will allow to acquire knowledge of archives as institutions, of its organization, rules of functioning, place in society, and most of all - knowledge of groups of inquirers, which archives encounter during their activities, with detailed identification of quality of relations between them. 
